\title{
A Review on the Contribution of Zakat and Taxation towards Economic Development Postulated by Two Contemporary Research Scholars
}

\section{Muhammad Aneeq Aiyman Roslan \& Mohamed Aslam Akbar \\ International Islamic University Malaysia}

\author{
Paper to be presented at the $4^{\text {th }}$ International Conference of Zakat (ICONZ) \\ 7-8 October 2020, Surabaya, Indonesia
}

\begin{abstract}
This paper is an attempt to analyze the contributions of zakat towards an economic system. Often zakat is viewed as a taxation tool which is focused on anti-poverty policies, especially during the classical Islamic Civilizations. The paper will review and discuss postulations bought by Russel Powell and his attempt to conceptualize zakat as a modern taxation system, and Monzer Kahf and his analysis of how zakat can truly impact economies in modern times. The precedes of such discussions have found that zakat is not an equal substitute for modernday taxation systems, and more importantly, it was never truly designed to solve all poverty issues in existence. There is a reconciliation that zakat plays a more important role in spirituality than it does in worldly pragmatism. Needless to say, zakat has contributed to poverty alleviation in the past, however along with other pivotal mechanisms concurrently in place such as Awqaf (endowments) and Infaq (disbursements)
\end{abstract}

Keywords: zakat, taxation, awqaf, infaq

\section{INTRODUCTION}

The commandment of zakat (alms) in Islam is widely understood by the mass public as a responsibility upon every Muslim who can afford it, especially as Islam has placed its obligation as one of the five pillars of religion. Zakat was first made compulsory upon all Muslim individuals in the second year of the Hijrah of the Prophet Muhammad SAW in Medina. The Holy Qur'an upholds zakat to a very high level of importance, having mentioned it 36 times on its own, while 26 mentions in which were found together with the word salah, the obligatory prayer (Saad and Al Foori, 2020). To that, one can easily deduce its strong correlation to taqwa in view of spirituality. There are several compilations of the hadith to which emphasize the real importance of zakat in Islam:

"Abu Huraira reported that the Messenger of Allah (may peace be upon him) sent Umar for (collecting) sadaqah (zakat), and it was said that Ibn Jamil, Khalid $b$. Walid and 'Abbas the uncle of the Messenger of Allah (may peace be upon him), refused (to pay it). Upon this the Messenger of Allah (may peace be upon him) said: Ibn Jamil is taking revenge but for this that he was destitute, and Allah made him rich. As regards Khalid, you are unjust to Khalid, for be reserved his armours and weapons for the sake of Allah, and as for 'Abbas, I shall be responsible for it and an equal amount along with it. And he again said: 'Umar, bear this in mind, the uncle of a person is like his father" (Sahih Muslim, Book 5)

In stressing the backlash to which on will face upon his/her refusal to pay zakat:

"Jabir b. Abdullah reported the Messenger of Allah (may peace be upon him) as saying: "No owner of camels or cattle or flock of sheep or goats who 
does not pay his due (would be spared punishment) but would be made to sit on the Day of Resurrection on a soft sandy ground and the hoofed animals would trample him with their hoofs and gore him with their horns. And none of them on that day would be without horns, or with broken horns. We said: Messenger of Allah, but what is due on them? He said: Lending of the male (for use) and lending of the bucket (used for drawing water for them) and for mating and milking them near water and providing them as a ride for the sake of Allah. And no owner of the property who does not pay zakat (would be spared punishment) but it (his property) would turn into a bald snake and would follow its owner wherever he would go, and he would run away from it, and it would be said to him: That is your property about which you were stingy. And when he would find no other way out he would thrust his hand in its mouth, and it would gnaw it like a male camel." (Sahih Muslim, Book 5)

The first Caliph Abu Bakr al-Siddiq stressed its going importance even after the passing of Prophet Muhammad SAW, to which he mentions that those who refuse to uphold their duties in paying their sum are against to be wage war.

Zakat, when comparatively discussed within conventional economic discourse, is often times drawn towards its similarities with modern-day taxation systems imposed in public finance. Taxation, through its theoretical origins, has different hypothetical objectives set in place. One of the first recourse of taxation, is the concept of removing externalities. This is often seen through ' $\sin$ tax' and specific taxation policies imposed on a particular good (Lockwood, 2017). The other origins arise from the notion of public sector revenue generation, often seen through the incomelwealth \capital gains tax implementation (Lockwood, 2017). Kaldor (1965) elucidates on the role in which taxation has to play in generating government revenue. Much to the extent, he opines that economic development and thus, poverty alleviation will require governments to generate sound fiscal revenue within the country, thus highlighting to need for economies to correctly tax their citizens and industries to be able to redistribute the income. It is not merely just on the premise of income taxation that administrative bodies have to focus upon. He also believes in the need for taxation to be imposed on agricultural productivity as well as commodities to ensure that governments have enough funds to implement their welfare policies.

Zakat, beyond its implications as a fard as well as a pillar in Islam, plays a bigger role in the Islamic economic system. In many instances, the institution of zakat is viewed as a fundamental tenet for a functioning Islamic economy. Not only in the aspect of fulfilling the spiritual commandments but as well as in the means of achieving sound public finances and attributing to a properly mechanized system for wealth redistribution. Imam al-Ghazali was known to have discussed the importance of zakat as a source of government revenue (Irijanto, Zaidi, Ismail $\&$ Arshad, 2015). In a similar perspective, it is often perceived that zakat portrays the socio-economic justice as advocated by Shari'ah, through the equity distributions it sought to do (Bakar \& Ghani, 2011). In many ways, it is a form of portrayal for Muslim societies to project their concern towards the welfare of disadvantaged and marginalized Muslims (Saad \& Al Foori, 2020). Hence, in our comparative discussion, we largely focus upon income and wealth taxation in comparison with zakat, 'sin tax' and the likes are best viewed akin to the other forms of taxation imposed within the Islamic civilizations, such as fai, ghanimah, jizyah, kharaj and ushr. Although Kaldor (1965) has rooted taxation with commodities and industry-based impositions, Islamic economics to some extent, can resonate with such mechanisms. 
If Muslims own an agriculturally based entity, then it is in the rightful obligations of every Muslim shareholder to pay zakat due to their ownership within such entity (Hasan, 2013). However, writings of Imam Abu Yusuf and Imam Abu Ubayd would also suggest that direct taxation on commodities was also well-practiced within Islamic civilizations back then akin to the systems discussed by Kaldor (1965).

The role of zakat goes beyond just religious interpretations from scripture. The current study is an attempt to analyze the contributions of zakat towards an economic system. The next section will discuss two issues. The first is the conceptual view of a conventional scholar on the idea of zakat and its parallel of an Islamic scholar. So the paper will review and discuss postulations bought by Russel Powell and his attempt to conceptualize zakat as a modern taxation system, and Monzer Kahf and his analysis of how zakat can truly impact economies in modern times. The second is a discussion surrounded the difference between zakat and taxation as a whole based on the suppositions that made in above mentioned scholarly works.

\section{ROLE OF ZAKAT IN ECONOMIC DEVELOPMENT: CONTEMPORARY RESEARCH SCHOLARS PERSPECTIVE}

\section{Russel Powell (2009)}

One of the few contemporary academics to delve into the topic of zakat is Russel Powell. Powell advanced a paper on the subject of "Zakat: Drawing Insights for Legal Theory and Economic Policy from Islamic Jurisprudence" in 2013, attempting to liberate conventional understandings of taxation by exploring the idea of taxation through Islamic concepts. Powell (2009) believes that many tend to turn to 20thcentury economic concepts to draw their structures on taxation and wealth redistribution mechanism. Yet, he claims these workings have been in existence long before that - even during Judaism and Christian periods. He describes that often people only view religious actions such as zakat as acts which are confined to charitable ones; hitherto he explains that in Islam, such conventions are not only a religious duty to help the poor, but throughout civilizations was in fact, heavily imposed by the state to collect such payments. It was unlike as perceived 'aspirational,' but a precedent of pragmatism.

Powell (2009) believes the interpretation of zakat to be based on the concept of sadaqah, which he refers to as a 'synonym.' Such extensions were believed to be a result of his interpretation of the translation of zakat itself in modern English (alms). Alms, as he defines it, was to do with the notion of giving charitably or beneficially in the means of wanting to help the poor and needy. He reconciles such views by construing that in parallel with the fuqaha (Muslim jurists), sadaqah shall remain in its meaning as a voluntary contribution to help the need, while Zakat is to be referred as a 'pious requirement.' He admits that sources of zakat's legality in Islam are rooted in the Qur'an and Sunnah; however, it elaborates that jurists such as alGhazali interpret to consolidate the ideas to which he understands was how the eight categorical breakdowns of the asnafs were given.

It is not only the system of zakat that contends as a substitute to certain taxation policies, but also the realization that zakat was in itself an embedded concept of what modern-day theory would label as, 'progressive taxation' policies. It is here where Powell (2009) highlights the application of nisab towards its superior relevance in modern-day systems. He opines that the nisab was supposedly an amount in which it was presumed to meet basic living expenses, and hence are then deductible for zakat. He highlights as a 
point of 'innovation' is the idea that zakat was multi-facet in terms of its incidence. To his understanding, rural industries such as agriculture and livestock incomes were deducted on gross wealth. Such was what he believed, complimented with waqf, facilitated the needs of the poor through the redistribution of the collections.

Powell (2009) has gone through the liberty of exploring common thoughts regarding classical Islamic scholars and the fuqaha's writings. It is through his careful compilation of understanding towards zakat to which he draws two principles relating to the legacy of zakat. The first principle is the concept of zakat being progressive in taxation and its attribution to wealth and income tax. However, Powell (2009) questions the efficiency in which zakat collection and distribution were carried out during the prior periods. The second principle that he highlights is in the notion of property and social justice in which ownership rights do not apply to pre-zakat income or wealth, as the poor have a right to a certain amount of the wealth/income. This is comparable to the conventional view whereby tax revenue is apportioned for a certain amount for the poor. It is indeed contrasted towards the libertarian ideas where pre-tax income is considered full ownership.

Much of the writing has been focused on the literature presented by prior scholars in Islam on their definitions of zakat, what it entails and the degree to what person/community would fall under the eight categories of the asnaf. Where Powell (2009) adds considerable value to the whole topic of zakat comes in two aspects; the first is his brief analysis of Muslim countries and how they have implemented zakat in their economy. The second is a quantitative regression analysis on the effectiveness of zakat towards promoting economic growth. This was then followed by the implications and recommendations of zakat moving forward.
The regression analysis effectively found that countries that have institutionalized zakat as a mandatory payment were seen to have higher wealth and economic equality compared to those who did not implement zakat at all or were mechanized on a more voluntary basis. Powell (2009) highlights the implications this has on countries who want to explore taxation systems to fund their public services particular in poverty alleviation. He contends that those countries may want to consider zakat as a means of taxation system to support the said public programs, however he also admits that in the current times we live in, most countries already have a form of mandatory tax system such as VAT or GST, rendering zakat as probably redundant. He asserts as well that the state needs to play a positive role in zakat wherein two thrusts need to be focused: Transparency and Oversight. Zakat institutions, be it through voluntary programs or mandatory state mobilized, need to have a transparent reporting system where the public's confidence can be held by knowing where funds are allocated, hence making it much more likely for people to participate within the system. Oversight is then concerned about ensuring that bodies and charities that are tasked to allocate zakat, be monitored on whether the funds reach the asnafs. Powell (2018) also holds the view that a governmentadministered zakat policy may be at risk of high administrative cost - bureaucracy, whereby charities have the upper hand in reducing that cost but at the expense of not reaching a more significant population size. $\mathrm{He}$ then uses previous examples of countries where governments can cap the administrative cost of bureaucrats (for instance, $1 / 8$ of the total collection) to remain as minimized as possible. He makes it very clear that zakat institutions managed by governments rather than charities tend to have a more significant impact on poverty. This is especially considering the number of resources, information, and data in possession, which could help target the 
asnafs more effectively. The next point in which he identifies as an issue is an idea that many Muslim countries today only remain as a Muslim majority and not an Islamic state. With that comes the notion of secularism and libertine laws and constitutions.

Given that upholding zakat is a religious mandate in Islam teaching such a system on a governmental basis may prove a challenge, especially in countries where large populations of non - Muslims exist. Hence, Powell Powell (2009) believes that such is why many governments chose to fund private charities/NGO's to administer zakat rather than have a proper body beneath them. However, to reconcile such issues, he believes that zakat effectively deals with the real problems of poverty, hence by navigating through such narratives may give governments the legitimacy to institutionalize zakat, provided that minority groups are not left out.

The precedes of such analysis then posses Powell to briefly explain eight challenges for countries to implement the institution of zakat. Firstly, the notion of progressivity: provided that the nisab correctly identifies the poverty line of income and only remains up until that point. All incomes that are deductible by zakat are constant at $2.5 \%$ beyond that amount and regardless of one's income, hence reducing its effect of progressivity. Powell also argues that zakat on sectors such as agriculture puts its stress on industries that are not generating the most massive profits in contemporary times. Secondly the notion of beneficiaries: Powell highlights once again that the principle at hand is the poor have a right on the wealth within the concept, but the challenge is posed on how to distribute the amount between the eight categories of asnafs (proportionately or depending on need). Thirdly, the notion of collection mechanism: some regimes for states that enforce zakat vary widely. Some have attempted to streamline the process by having depository institutions implement the contribution on a fixed date every year. Some have local enforcement personnel who estimate the productivity of agricultural resources. However, some voluntary systems result in higher participation and collection rates than countries with mandatory zakat. Fourthly, the need to question on administrators: a government run agency will mean more cost, however in some countries the use of savings institutions like banks and such to automatically deduct zakat have proven almost zero cost in such operation. Fifthly, the idea of encouraging piety: Powell highlights that venturing on the notion of increasing piety as a policy goal may not be pragmatic and opines that voluntary zakat collections are more than likely bound to collect lesser amount compared to enforced systems. Powell's sixth notion is the option to excise new ijtihad: he focuses this point on the idea that classical fuqaha (Muslim jurists) opines that the nisab be calculated on a basket of commodities (gold, silver and etc.), however he cites that recent juristic opinions have argued the need to review such basis on the calculation of the cost of living according to other measures this is so that the progressivity can be maintained. Seventhly, the notion of minorities: the idea that zakat is an Islamic obligation and is usually imposed on Muslims strikes the concerns of identity segregation between citizens - possibly putting non-Muslims at a legal disadvantage. Finally, the eighth notion is the integrational economic system: zakat was set out as religious duty, with socioeconomic outcomes favorable to society, it works in the dimension of relief for the poor and disadvantaged, however beyond that context zakat remains very limited to the whole picture.

\section{Monzer Kahf (1999)}

An attempt to study the theoretical underpinnings of zakat and its practice in history and contemporary times can be traced to the writings of Kahf (1999), a 
paper titled "The Performance of the Institutions of Zakat in Theory and Practice". Within this paper Monzer Kahf discusses some salient issues that deal with zakat: i.e., zakat during the time of the Prophet, the fiqhi opinions of zakat, the way contemporary Islamic economist consider zakat and the role it has in the Islamic economy, reviewing theoretical estimations of zakat proceeds concerning the GDP, the implementation of zakat in certain countries and so on.

In his analysis of the zakat in the time of the Prophet, Kahf (1999) writes that the Prophet used to send out workers to collect and distribute zakat, which was mainly surrounded around livestock and agriculture. He notes that it is hard to identify the level of zakat proceeds at the time but contends that one Dirham was enough to sustain a family of four for a day - an approximation extended to unskilled labor in agriculture or employment in government services. Thus zakat was predominantly imposed on agricultural products, livestock, trade inventories, gold and silver. He writes the land was useless unless it was used for cultivation. It was also the fair realization that poverty continued to exist in the time of the Prophet up until the Caliph Umar bin Khattab conquered the North Arabian Peninsula, where large incomes were then starting flow within the economy. Essential to note that irregular revenue such as war bounties was usually distributed with a minimal left to keep for the treasury of precautionary savings, leading to the notion that zakat alone was not enough to raise the economy. Hence it needs to be understood that zakat alone had not been a sufficient system to eradicate poverty at once - even in a society where very little are within poverty. To that, Kahf (1999) delineates his findings that if it were not for voluntary contributions filling in the gap, the rich would have seen higher tax incidence to fund the welfare programs. This can be traced to the Quran and Sunnah whereby its indication in zakat alone to solve poverty was made clear by the need for Muslims to partake in activities of awqaf and infaq simultaneously - a multi-facet system. It is an ideology embedded in Islam on the basis of social solidarity and mutual support, driven in the spirituality to please Allah SWT, making the able and rich morally and legally responsible for acting in what they can within the realms of helping the needy. What is considered zakatable at the time had to be taken on the notion of the fulfillment of one's ability to meet nutritional, social, and religious requirements of his/her family, to which its excess will then be subject to zakat.

The concepts and views of the classical fuqaha (Muslim Jurists) that were reported by Kahf (1999) did not have changed significantly to what it was previously because the economic structure of the economy at the time remained relatively similar to the times of the Prophet; it was dependent on agriculture with some innovations in manufacturing of clothing. He writes that it was during this time where vegetables and honey were included in zakatable items due to their productivity, and the establishment of categorical items according to amwal zahirah (apparent items) and amwal batinah (undisclosed items). By and large, the classical fuqaha emphasized the aspect of zakat for purity and sanctification. He notes that Umar al-Khattab and Jaber in Yemen stressed the importance of awqaf and saw its expansion during their times helping the poor and needy on a bigger scale. That, coupled with zakat and increasing productivity through economic growth, saw the eradication of poverty during those periods. Among others, it was also the cultivation of concepts based on qana'ah and self-reliance proved that many did not want to opt for zakat but chose to find a means of moving away from hardship. Lastly, it was also the view of fighting corruption and public sector efficiency that increased government revenues to help fund the poor. 
Zakat viewed in modern times have pointed to its effectiveness in solving macroeconomic issues within an economy. It was found that through the Keynesian consumption function, the incidence of zakat and prohibition of extravagance would lead to in general, a lower level of propensity to consume. There is also the contention that introducing zakat in the economy leads to a neutral effect whereby the canceling mechanism of the overall effects between the poor and rich would come into play - thus stressing on the notion of the Islamic principle of helping the poor more than actually seeing it as a macroeconomic effect. The notion of encouraging investment and on idle assets, which would be in turn bound for incidence on zakat in tandem with the distribution of zakat to debt-ridden individuals, can create an overall demand effect that can create jobs and transform workers into more productive individuals. There is also the notion of zakat having an increasing effect on aggregate supply through higher labor participation within the economy. Amongst others, there is also the effect of zakat viewed from the IS-LM model, which would lead to higher growth within the country. Other studies have also postulated that zakat could increase higher returns on capital along with higher economic growth. And most importantly, the idea that zakat is a very targeted program means that it addresses issues that are very specific to the poor households, which may lead to a more equitably distributed wealth mechanism.

The discussion in section four is broadly highlighting different studies which have attempted to see how much zakat is attributed to the GDP of an economy. There is not much to discuss within this section. However, it is helpful to note that most of the studies identified that zakat would come to between $2-6 \%$ of the GDP, with a prior study by Kahf himself who sought to identify the zakat attribution in 3 different models. The studies varied according to the definition of what would be included as the nisab; where the third model was found to generate the highest having defined the nisab to include the capital value of fixed assets in all sectors at a rate of $2.5 \%$. His first model saw the lowest, where the nisab was defined to cover agriculture output, livestock, trade inventory, and cash holdings.

The preceding section does not have much contention, a simple summary of countries that have implemented zakat and the systems adopted by them. Much of the writing is very similar to the analysis conducted by Powell (2009) to differentiate the different systems existing in modern Islamic economies today. However, Kahf highlights in this section with his lack of reliability on data existing today to help with future analysis, and the high incidences of fraud, evasion as well as other moral aspects have seen to reduce its effectiveness, and he believes that much of zakat today is borne on cash holdings, which he contends is very hard to materialize in real life.

\section{DISCUSSION}

The views of both Powell (2009) and Kahf (1999) have shown some significant similarities between them. One of the more obvious ones is that within this context, both of these authors have shown a significant commitment towards wanting to make zakat a relevant system according to contemporary times. More importantly, in doing so, they have each tried to remain within the limits of what previous modern scholars have elucidated and tried to design its relevancy from those points, and one can easily identify that the common issues in which Kahf (1999) and Powell (2009) highlight is the aspect of nisab and the base of zakat. Much of their discussion has shown that a lot of what zakat will become today, is very much dependent on what bodies, organizations and governments choose to opt in defining how much is the zakatable base to be deducted. They have also gone to analyze the different 
implementations of zakat within similar countries and have relatively provided a very similar analysis in terms of the plethora of mechanisms available. Powell (2009) has even called for a review on what is considered as the nisab and issues that need for new ijtihad to truly reflect living standards today. This is very important in terms of sustaining the effectiveness of zakat as a welfare distribution system. Given that the nisab used in many cases are based on the conclusions of the classical fuqaha (Muslim jurists), living standards and economic systems have changed quite drastically in comparison to then, hence basing the nisab on such precedence may result in an underestimation of what is considered zakatable, therefore issuing a heavy burden on households who can not pay, but have been put inside the category of those who have to.

One of the keys defining the difference between these two authors is effectively where their overall contributions seem to be focused on. Powell (2009) has written a piece of work that seems to be more aimed at how zakat can itself be implemented through a modernized taxation system, whereby Kahf (1999) emphasizes more on how zakat can play an exemplary role in providing positive feedback to the macroeconomic outlook of an economy. Perhaps, it is wise to understand that Powell at this juncture (apart from briefly explaining where zakat was mainly used in previous civilizations), seems to be more concerned about the notion of whether zakat should be voluntary or be implemented as a mandatory deduction akin to income tax. More importantly, the attempt by Powell (2009) can be lauded in the sense that he is trying to issue a framework that can be built upon for economies to follow. This is important given that the previous Islamic civilizations have worked on zakat to be collected mandatorily through the government. Yet, at this juncture, it is also significant to concern that how zakat is operating within the country has to be rooted back to the notion of faith. Faith means harping on the notion that one who truly believes in the religion, will pay zakat in any means regardless of whether the state will knock on his/her doors or not. Hence, analyzing the effects of zakat on the macroeconomic perspective, as done by Kahf (1999), is merely dependent on institutions that Powell (2009) would have explained, but towards the notion of commitment, whereby such is only truly realized when faith is properly understood. Even in the times of the Caliphs, it was faith that allowed zakat institutions to flourish more than anything, public enforcement on the process may just be merely viewed as more of an accommodative step towards easing the collections. Truly, as Kahf (1999) rightly puts; zakat is a testament of one's faith to submit to God and His commandments; inevitably, zakat is not the end solution of public welfare systems, or poverty eradication policies (although it will greatly assist), those policy objectives has to be realized on the footprint of multiple other policies than become interrelated to each other (such as awqaf, fai and the likes). In fact, Kahf (1999) stresses that the success of the Islamic caliphs in eradicating poverty was since awqaf was also at high levels in tandem with zakat collections.

Kahf (1999) analyses on the impacts of zakat through the macroeconomic perspectives of employment, aggregate demand, and aggregate supply light the discussion where many have seemed to neglect. The fact remains that, zakat has its capability to bring ominous effects to an economy if conducted properly. But if anything, it is not so much of zakat itself that tries to bring about change, but perhaps the underlying notion beneath it. It is the conceptual thought that in any economy (typically Islamic), where a system of properly redistributed mechanism are in place, hoarding of wealth is reduced to its minimum, and welfare policies are well designed and its effects are bound to flourish the economy. This is true as we 
have seen in these writings, the whole reason why poverty can be erased is because previous civilizations had in place a system that ensured those targets were met. Similarly, the study by Kahf shows the need for economic systems to always have a focus on wanting to reduce inequality and lifting the poor from their plights because it is through junctures as such where economies will truly flourish. Zakat represents the base to which all this should be built upon, the creativity lies in administration to go beyond and adapt accordingly.

Kahf's very idea that people often misconceive is that zakat can act as the main solution to poverty eradication. Unfortunately, much of such views stretch the ability of zakat to reach those targets, especially given that incomes are usually subjected to a fixed rate of deductibles. This then stresses the more significant outlook in which zakat tries to promote investment. Even Powell (2009) contends to such view. As Kahf (1999) explains, the times of the Caliphs saw high levels of economic growth and productivity, thereby allowing for labor to become employed in the industries operating then, and receive a sufficient amount of income that moves one away from needing to rely on zakat to meet daily needs. The idea of investment here is then that people who do own excess amounts of wealth, income, or money holdings are best to put that into productive use that can help stimulate the economy. Verily, such effects are what zakat provides a form of impetus and not as just as the basic notion of realizing every capable man's duty for the poor. However, even though zakat on its own may not be an effective tool for poverty eradication, it need be stressed that the idea that it is very targeted to the eight asnafs categorized, means that the mechanism in place in contrast to the many others that exist will in its default be used for poverty-related issues, hence at the very least; in any fiscal plan that would be designed can never truly sideline the poor because of zakat on its own acts as a stop-gap between the bare minimum of how much goes to the poor.

One of the more distinctive differentials in the thoughts of Powell (2009) and Kahf (1999) is the definition of what zakat is understood to them. Powell (2009) especially, seems to have entangled his understanding of zakat when he defines it though what he understands, and alms and somewhat extends that to also mean sadaqah based on interpretations from the text. Although he reconciles by simplifying zakat to mean sadaqah that is more enforced, it does reflect a differing viewpoint from most traditional understanding. Kahf (1999) makes it very clear that his understanding of zakat is understood as a completely separate issue from sadaqah, as he elucidates on its significance through its historical implementation in the second year of the Hijrah, whereby sadaqah are explained in different jurisdictions.

More often than not, the analysis that precedes within the subject of zakat tends to witness the hefty comparison of zakat as a substitute for taxation systems in existence today. Powell (2009) has gone to perform something very similar. The sole purpose of his paper was to realize zakat as a means of taxation policies that could well be achieved in several other countries. There is every bit of zakat that makes it portray as a parallel to something such as income tax or wealth tax, the rate imposed, collection systems, and its redistributive mechanisms. However, the Islamic principle from zakat is not entirely to see a system that perfectly redistributes wealth and thence lower inequality, because as Kahf (1999) correctly highlights, even during the time of the Prophet when zakat was implemented, the poor still persisted. So, if zakat was sought to remove inequality, why then was that not the true case? Surely, the system would have provided enough and thence irrelevance of other public sector revenues such as fai, ghanimah or ushr. More than anything, it is 
the symbolic notion that zakat entails, and this too was nicely explained by Kahf (1999). It is through zakat that humans realize their brotherhood, and the embedded commitment from one to those who are not as well off as they are, it is through zakat Muslims understand that wealth is never completely theirs to keep, in fact Powell (2009) subtly mentions this concept when he delineates on the idea that pre-zakated wealth or income is not absolute ownership, wherein the poor have a born right upon some of that wealth/income. More importantly, it is through zakat that one truly realizes the fairness that Muslims realize that their worship is not just through salah, but through obligating their lifestyles in different contexts to fulfill the commandments. It is more of religious duty, than it is a Public finance tool.

In extension to the previous point, we reckon Powell (2009) though having overtly used zakat as an absolute tax system, there is an interesting nuance that has come out of it. Powell (2009) has mentioned the idea of a wealth tax surrounding zakat, and in fact, Kahf (1999) had shortly touched on this in one sentence or two. Zucman and Saez (2019) have extensively discussed the notion of implementing a $1 \%$ tax on the wealth of the $1 \%$ of American citizens, and to that, they highlight the significant amounts of returns accruing from just simply taxing the superrich at a shallow marginal rate. This concept has seen to be realized in the zakat system - any Muslim who holds wealth (separate to income) beyond the minimum amount will be subject to zakat of $2.5 \%$, in fact being higher than the $1 \%$ which was proposed by Zucman and Saez (2019). Assuming the similarities of the system, an Islamic economy should greatly benefit from a zakat based system that already focuses on deductibles on wealth assets. However, it is essential to realize that these effects would only much resemble a spillover effect of zakat and not its sole purpose for implementation.
The precedes of the previous paragraph means that Powell (2009) attempt to inform zakat as a substitute to a system such as income tax may not be as well received. Whether there exists a system of income tax or not, zakat still must persist as an institution to facilitate the worship of Muslims, as much as mosques are needed for the community to perform their salah (obligatory prayers).

A common and well perceived ideal in which these two scholars share, which is central to the success of zakat, is the notion of good governance and bureaucratic inefficiencies. Kahf (1999) highlighted for the efficient operatives of administrative officials during the times of the Caliph in which allowed for their revenues to be fully maximized. Similarly Powell (2009) stresses the need for governments to be transparent as well as well monitored in the collections and distribution of zakat funds. Powell (2009) opines that trust within the system will allow for more encouragement within society to pay their zakat in institutions. This is an important aspect because as far as data is concerned; governments do not truly knows whether an individual has paid his zakat even when he opts out of a system. Being a religious duty, the onus is on the individuals to pay their dues, and one cannot deny that some have gone their own way to directly give that money on their own initiative rather than actually through NGO's or governmental organizations. Perhaps in Powell's view this is more of observed through the lens of efficiency, but as far as Kahf or any Muslim would be concerned is the idea that anyone working on behalf of collecting the zakat funds is doing so as a responsibility imparted to look after funds neither belongs to them and is being done so through a religious means - making it even more dutiful on moral grounds to stress the importance of accountability and good governance. 


\section{CONCLUSION}

The discussions offered by Powell (2009) and Kahf (1999) provide some very insightful thoughts on zakat and its role in Islam. Verily we can conclude that Powell (2009) has made a tremendous effort in wanting to realize zakat as a fully functioning taxation system in modern Islamic economies through implementation and its benefits. Kahf (1999) has shown his commitment to sparking the narrative that zakat on its whole, whether institutionalized in a country or not, can be a significant contributor to economic systems existing today. Moreover, the notion of zakat playing a substantial role in poverty alleviation cannot be disputed. However, the realization that zakat was never meant to be a wholesome policy that defeats all poverty issues, need to be realized by many scholars today. Zakat can indeed contribute efficiently to the poor if awqaf and infaq play its equivalent role in helping to redistribute wealth. The fact remains that zakat remains as a symbolism towards faith beyond salah - and it is exactly that which is what it was sought to do. The effects it brings to an economy should only be seen as secondary gains from such commandments.

Going forward, it is pertinent that scholars (especially Powell) evaluate zakat as a form of public policy along with the other aspect of revenue collecting mechanisms. This is because citing literature from historical Islamic civilizations means that many of the revenues generated during those periods were attributed to other factors namely fai, ghannimah, ushr and the likes. Perhaps, if zakat was to really be analyzed as a taxation system, then it would only make sense to do so if the other Public Finance tools used back then were concurrently viewed to be implemented together; only then we can see a fair comparison of taxation systems between conventional economics and Islamic economics.

\section{REFERENCES}

Abu Bakar, M., and Abd Ghani, A. (2011). "Towards Achieving the Quality of Life in the Management of Zakat Distribution to the Rightful Recipients (The Poor and Needy)", International Journal of Business and Social Science, 2(4), 237-246

Hasan, A. (2013). Who needs to pay Zakat: A focus on legal entities? National Business Zakat Symposium. https://www.maybank2u.com.my/iw ov-resources/islamic-my/doc ument/ my/en/islamic/scoe/knowledgecentre/researchpaper/Who_Needs_to_Pay Zakah.pdf

Irijanto, T. T., Shah, M. A., \& Ismail, A. G. (2013). The Thoughts of Economic Growth Theories of Classical Muslim Scholars, A Contribution. TRIKONOMIKA, $12(2), \quad 168$. https://doi.org/10.23969/trikonomika .v12i2.478

Kahf, M. (1999). The Performance of the Institution of Zakah in theory and practice. International Conference on Islamic Economics. Kuala Lumpur

Kaldor, N. (1965). The Role of Taxation in Economic Development. Problems in Economic Development, 170-195. https://doi.org/10.1007/978-1-34915223-0_8

Lockwood, B., \& Taubinsky, D. (2017). Regressive Sin Taxes. NBER Working Paper, 0. https://doi.org/10.3386/w23085

Powell, R (2009) Zakat: Drawing Insights for Legal Theory and Economic Policy from Islamic Jurisprudence. University of Pittsburgh Tax Review, 7(43), Seattle University School of Law Research Paper No. 10-17, Available at SSRN: https://ssrn.com/abstract $=1351024$ 
Saad, A.Y.Q. and Al Foori, A. M. (2020). Zakat and Tax: A Comparative Study in Malaysia. International Journal of Innovation, Creativity and Change, 10(12), https://www.ijicc. net/images/vol10iss12/101213_Saad _2020_E_R.pdf

Zucman, G. and Saez, E. (2019). Progressive Wealth Taxation. BPEA Conference Drafts, September 5-6, 2019.

https://www.brookings.edu/wpcontent/uploads/2019/09/Saez-

Zucman_conference-draft.pdf

Muhammad Aneeq Aiyman Roslan

Department of Economics, Kulliyyah of Economics and Management Sciences, International Islamic University Malaysia aneeq.roslan@gmail.com

Mohamed Aslam Akbar

Department of Economics, Kulliyyah of Economics and Management Sciences, International Islamic University Malaysia aslamakbar@iium.edu.my 